\title{
Progression of Liver Fibrosis in HIV/HCV Genotype 1 Co-infected Patients is Related to the T Allele of the RS12979860 POLYMORPHISM OF THE IL28B GENE
}

\author{
P. Lutz ${ }^{1}$, J.-C. Wasmuth ${ }^{1}$, H.-D. Nischalke ${ }^{1}$, N. Vidovic ${ }^{2}$, F. Grünhage ${ }^{1,3}$, F. Lammert ${ }^{3}$, J. Oldenburg'2, \\ J. K. Rockstroh ${ }^{1}$, T. Sauerbruch ${ }^{1}$, U. Spengler ${ }^{1}$ \\ ${ }^{1}$ Department of Internal Medicine I, University Hospital Bonn, Bonn, Germany \\ ${ }^{2}$ Institute for Experimental Hemostasiology and Transfusion Medicine, University Hospital Bonn, Bonn, Germany \\ ${ }^{3}$ Department of Medicine II, Saarland University Hospital, Homburg, Germany
}

\begin{abstract}
Objective: HIV/HCV co-infection is characterised by accelerated progression of liver disease. Recently, the rs12979860 C/'T polymorphism in the IL28B gene has been linked to progression towards cirrhosis in $\mathrm{HCV}$ mono-infected patients and to treatment response of $\mathrm{HCV}$-infection in HIV/HCV co-infected patients. Our aim was to clarify by non-invasive techniques if this polymorphism affects fibrosis progression in HIV/HCV co-infection.

Methods: In a cross-sectional design, liver stiffness (transient elastography), surrogate markers of liver fibrosis (APRI and FIB-4 scores) and rs12979860 genotypes were analysed in $84 \mathrm{HCV} / \mathrm{HIV}$ co-infected patients. IL $28 \mathrm{~B}$ genotypes were determined by real-time PCR using a light cycler. In $56 \mathrm{HIV} / \mathrm{HCV}$ co-infected patients we also studied progression of fibrosis in relation to rs $12979860 \mathrm{C} / \mathrm{T}$ genotypes over two years.

Results: $82 \%$ of the patients were on HAART $(74 \%$ without detectable HI viremia) and $67 \%$ were haemophiliacs, respectively. HCV genotype 1 was present in $62 \%$. Cross-sectional median liver stiffness was $7.4 \mathrm{kPa}$ and correlated with APRI and FIB-4 scores (t $=0.6$ each, $p<0.001)$. Frequencies of $1 \mathrm{~L} 28 \mathrm{~B}$ genotypes were: CC $50 \%$, CT $43 \%$ and $\mathrm{T}^{\circ} \mathrm{T} 7 \%$. In the cross-sectional analysis liver stiffness values were not different between the various $I L 28 B$-genotypes. Upon follow-up under HAART carriers of a $\mathrm{C}$ allele did not show further progression, while liver stiffness significantly increased in $\mathrm{HIV} / \mathrm{HCV}$ co-infected patients with the T allele $(p=0.047)$.

Conclusion: Although progression of liver fibrosis was low under HAART in our cohort, progression was more pronounced in HIV/HCV genotype 1 co-infected patients with the $T$ allele.
\end{abstract}

Key words: IL28B, polymorphism, liver fibrosis, transient elastography, HIV, HCV

\section{INTRODUCTION}

Liver disease is the main cause of mortality in about 10 per cent of HIV infected patients in Germany [1]. To a large degree, liver discase among HIV patients is caused by chronic HCV infection, because both viruses share similar ways of transmission [2]. Treatment of $\mathrm{HCV}$ infection is difficult in HIV/HCV co-infected patients, as immunological dysfunctions still persist under HAART [3]. Data on the progression of liver fibrosis in HIV/HCV co-infected patients in the HAART era are contradictory, ranging from rapid progression to advanced fibrosis in some cohorts $[4,5]$ and to outcomes similar to $\mathrm{HCV}$ mono-infection [6, 7]. Recently, polymorphisms in the IL $28 B$ gene have been linked to spontaneous clearance of hepatitis C [8]. Although the T allele of the rs128979860 IL 28B polymorphism has been reported to be more frequent in HCV infected patients with liver cirrhosis than in healthy controls or patients with cirrhosis of non-viral origin [9], it is not known whether genetic variation in the IL 28B gene also affects progression of liver fibrosis in $\mathrm{HIV} / \mathrm{HCV}$ co-infected patients.

Assessing liver fibrosis is difficult in HIV/HCV coinfected patients because liver biopsy, the current diagnostic gold standard, is limited by small sample size, poor patient acceptance and the risk of possibly lifethreatening complications [10]. Transient elastography is a non-invasive method to measure liver stiffness, which has been evaluated with good results in HIV/HCV co-infected patients [11, 12]. As an alternative, certain serum markers have been proposed to indirectly reflect the degree of liver fibrosis. In particular, APRI [13] and FIB-4 [14] scores, which rely on standard laboratory values, have been established as surrogate markers for liver fibrosis.

Using transient elastography, APRI and FIB-4 scores as surrogate markers of liver fibrosis, we studied the effect of the rs $12979860 \mathrm{C} / \mathrm{T}$ polymorphism approximately 3000 base pairs upstream of the II $28 B$ gene on progression of liver fibrosis in HIV/HCV coinfected patients.

\section{PATIENTS AND METHODS}

\section{PATIINTS}

We analysed in a cross-sectional design all 84 patients with $\mathrm{HIV} / \mathrm{HCV}$-co-infection whose DNA was available for genotyping of the IL28B-SNP and who had at 
least one valid assessment of liver fibrosis by transient elastography between January 2005 and February 2009. To assess progression of liver fibrosis, we studied all the $56 \mathrm{HIV} / \mathrm{HCV}$ co-infected patients from the above-mentioned cohort who had received at least two follow-up assessments of liver fibrosis till September 2010. Informed consent was obtained prior to the study, and the protocol had been approved by our local ethics committee in accordance with the Declaration of Helsinki. Demographical and clinical data as age, gender and medication were recorded in all patients. Parts of the clinical data of our patients were published previously in studies on the evaluation of transient elastography $[15,16]$.

\section{METHODS}

\section{Laboratory analysis:}

Detection of HCV and HIV antibodies, determination of HCV and HIV viral loads as well as CD 4 counts, liver function tests and platelets counts were done by routine procedures [17]. The AST to platelet ratio index [APR] and FIB-4 scores were calculated as published $[13,14]$.

We genotyped all patients for the IL28B rs12979860 SNP with the commercially available Light SNiP rs12979860 hu IL 28B assay (TIB MOLBIOL, Berlin, Germany).

Transient elastograpby (TE):

In transient elastography the tip of the transducer is placed on the skin between the rip bones over the right lobe of the liver, so that an clastic shear wave is propagated through the tissue. The velocity of this wave, which is directly related to tissue stiffness, is measured by ultrasound. The tissue covered by this measurement corresponds to a volume of about $1 \mathrm{~cm}$ width and $4 \mathrm{~cm}$ length, in a depth between $25 \mathrm{~mm}$ and $65 \mathrm{~mm}$ below the skin. Results are expressed as median stiffness $(\mathrm{kPa})$ of at least ten measurements. $\mathrm{Pa}$ tients in whom it was not possible to obtain a minimum of 10 measurements with a success rate of at least $60 \%$ and an interquartile range of less than $30 \%$ of the median were excluded [11].

\section{Statistics}

Statistical analysis was done with SPSS release 17.0 (SPSS, Munich, Germany). Data are given as means \pm standard deviation, unless stated otherwise. Quantitative data were analysed using the Mann-Whitney-U test, the Wilcoxon-signed-rank test or the Kruskal-Wallis test, as appropriate. Fisher's exact test was used for qualitative data. Correlation was done using Spcarman's rank correlation. As the frequency of the T'T genotype of the rs 12979860 polymorphism is low and a recessive effect of $C$ allele was proposed before $(8,20-22)$, we combined the CT and T'T genotype for comparison with the $\mathrm{CC}$ genotype when a difference was found.

\section{RESUITS}

\section{CrOSS-SECTIONAL. STUdY}

$76(90 \%)$ patients were male with a median age of 43 years, $56(67 \%)$ had haemophilia. $52(62 \%)$ of the patients were co-infected with $\mathrm{HCV}$ genotype 1, 67 $(82 \%)$ received HAART and $\mathrm{HI}$ viremia was below the level of detection in $62(74 \%)$ patients. Median liver stiffness (transient elastography) was $7.4 \mathrm{kPa}$. Median APRI and FIB-4 scores were 0.9 and 1.6, respectively. The distribution of IL $28 B$ rs12979860 genotypes (CC in $42(50 \%), C^{\prime}$ in $36(43 \%)$ and TT in $6(7 \%)$ patients) was in accordance with the Hardy-Weinberg equilibrium. Further patient details as well as separate information on the subgroup of the longitudinal analysis are summarized in Table 1.

As expected APRI and FIB-4 scores correlated significantly with the results obtained by transient elastography $(\mathrm{r}=0.6$ for both, $\mathrm{p}<0.001)$. However, we could not find any significant correlation between liver fibrosis and rs12979860 genotypes irrespective of the choice of surrogate markers (Table 2). There was also
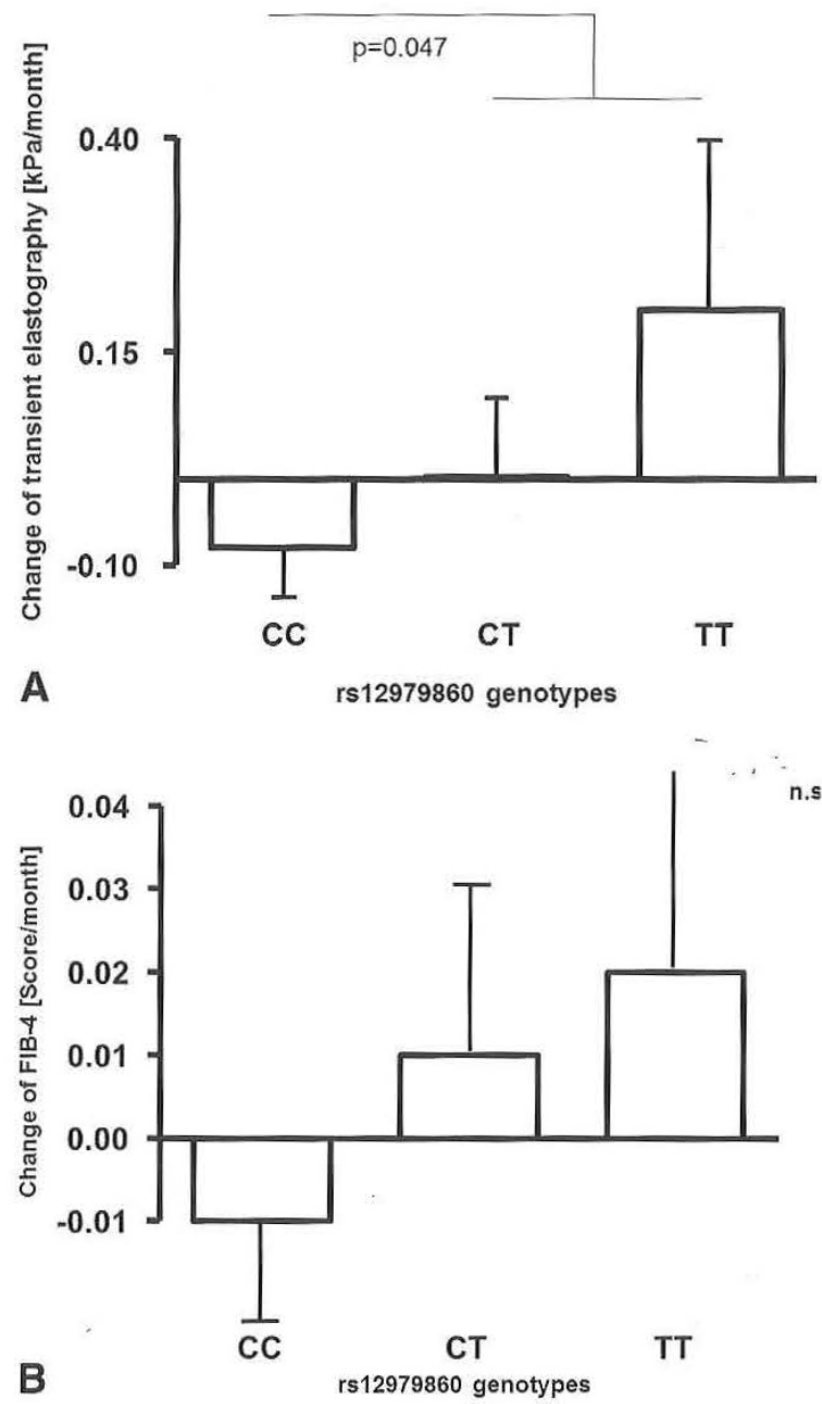

Fig. 1. Different rates of liver fibrosis progression in patients co-infected with HIIV and HCV genotype 1 depending on the $I L 28 B$ genotype (error bar $=$ standard error $)$.

$\Delta$ Evaluation by transient elastography, $\mathrm{p}=0.047 \mathrm{for} \mathrm{CC}$ versus $\mathrm{T}$ allele.

B Evaluation by FIB-4 scores, $\mathrm{p}=$ not significant for $\mathrm{CC}$ versus $\mathrm{T}$ allele. 
Table 1. patient characteristics.

\begin{tabular}{|c|c|c|}
\hline & Cross-sectional study & Longitudinal study \\
\hline Number of patients & 84 & 56 \\
\hline Sex: male & $76(90 \%)$ & $51(91 \%)$ \\
\hline Age (median, range) & $43(24-70)$ & $41(24-62)$ \\
\hline $\begin{array}{l}\text { Risc factor } \\
\text { Haemophilia } \\
\text { i. v. drugs } \\
\text { man who have sex with man }\end{array}$ & $\begin{array}{l}56(67 \%) \\
22(26 \%) \\
6(7 \%)\end{array}$ & $\begin{array}{l}35(63 \%) \\
16(29 \%) \\
5(9 \%)\end{array}$ \\
\hline HCV-RNA negative & $14(17 \%)$ & $5(9 \%)$ \\
\hline $\mathrm{HCV}$ viral load $>800000 \mathrm{IU} / 1$ & $55(66 \%)$ & $39(70 \%)$ \\
\hline $\begin{array}{l}\text { HCV-Genotype } \\
1 \\
2 \\
3 \\
4\end{array}$ & $\begin{array}{l}52(62 \%) \\
6(7 \%) \\
13(16 \%) \\
4(5 \%)\end{array}$ & $\begin{array}{l}39(72 \%) \\
3(6 \%) \\
10(19 \%) \\
2(4 \%)\end{array}$ \\
\hline HAART & $67(82 \%)$ & $46(84 \%)$ \\
\hline PI-based HAART & $50(75 \%)$ & $37(80 \%)$ \\
\hline NNRTI-based HAART & $17(25 \%)$ & $9(20 \%)$ \\
\hline$<50$ HIV copies / ml & $62(74 \%)$ & $43(77 \%)$ \\
\hline CD4-Count (median, range) $[\mathrm{cell} / \mu \mathrm{l}]$ & $397(10-1757)$ & $394(10-966)$ \\
\hline AST (median, range) [U/1] & $47(21-197)$ & $48(21-197)$ \\
\hline ALT (median, range) [U/I] & $72(8-275)$ & $77(16-275)$ \\
\hline Platelets (median, range) $[\mathrm{T} / \mathrm{l}]$ & $160(9-337)$ & $148(9-325)$ \\
\hline Stiffness (median, range) $[\mathrm{kPa}]$ & $7.4(3.3-48)$ & $7.8(3.3-48)$ \\
\hline APRI (median, range) & $\begin{array}{l}n=75 \\
0.9(0.3-43.2)\end{array}$ & $\begin{array}{l}n=52 \\
1.1(0.4-43.2)\end{array}$ \\
\hline FIB-4 (median, range) & $\begin{array}{l}\mathrm{n}=75 \\
1.6(0.5-50.3)\end{array}$ & $\begin{array}{l}n=52 \\
1.6(0.5-50.3)\end{array}$ \\
\hline $\begin{array}{l}\text { IL } 28 B \text { genotype: } \\
\text { CC } \\
\text { CT } \\
\text { T゙T }\end{array}$ & $\begin{array}{c}42(50 \%) \\
36(43 \%) \\
6(7 \%)\end{array}$ & $\begin{array}{l}26(46 \%) \\
25(45 \%) \\
5 \quad(9 \%)\end{array}$ \\
\hline Time of follow-up (median, range) [months] & & $25(5-50)$ \\
\hline
\end{tabular}

no significant difference in liver stiffness levels with respect to different $\mathrm{HCV}$ genotypes. Since the rs12979860 C/T polymorphism has predominantly been described in patients with $\mathrm{HCV}$ genotype 1, we analysed this subgroup separately, but could not find any effect. However, CD4 cell counts differed significantly between IL28B-genotypes, being lowest in homozygous carriers of $\mathrm{T}$ alleles.

\section{LONGITUDINAL. STUDY}

Next, we hypothesized that progression rates were affected by the IL28B polymorphism. This patient subgroup corresponded closely to the entire study group (Table 1) with a baseline liver stiffness of $7.8 \mathrm{kPa}$, which was significantly correlated to APRI score (median 1.1; $\mathrm{r}=0.6, \mathrm{p}<0.01$ ) and FIB-4 score (median 1.6; $r=0.7, p<0.001$ ). Median follow-up was 25 months (range $5-50$ months). Overall, changes in liver fibrosis were rather low ( $\Delta$ liver stiffness: $1.3 \mathrm{kPa}$ $\pm 8.3 \mathrm{kPa}, \Delta \mathrm{APRI}=-0.9 \pm 6.2, \Delta \mathrm{FIB}-4=-0.6 \pm 7.0)$ and these differences did not achicve statistical significance, but still revealed a significant correlation of $\Delta$ liver stiffness versus $\triangle A P R I$ or $\triangle F I B-4$ score $(r=0.4$ each, $p=0.004$ and $p=0.002$ respectively). Considering all HCV genotypes together there was no variation in fibrosis progression between the different IL $28 \mathrm{~B}$ genotypes. However, a subgroup analysis in our HCV genotype 1 co-infected patients revealed a slight decrease in liver stiffness in rs12979860 genotype CC patients, no change in heterozygous $\mathrm{C}$ carriers and a slight increase in genotype TT patients (Fig. 1). This effect achieved statistical significance when carriers of the $\mathrm{T}$ allele were compared to patients with the CC genotype ( $p=0.047$, Table 3 ). Similar to liver stiffness, changes in FIB-4, but not in APRI scores, revealed a gradual increase in relation to the number of $\mathrm{T}$ alleles ( $\mathrm{p}=$ not significant). There was no significant difference in control of $\mathrm{HI}$ viremia or CD4 counts between these groups. 
Table 2. Differences between patients with $\mathrm{rs} 12979860 \mathrm{C} / \mathrm{T}$ genotypes in the cross-sectional analysis.

\begin{tabular}{|c|c|c|c|c|}
\hline & $\mathrm{CC}$ & CT & T'T & $\mathbf{P}$ \\
\hline Patients & $42(50 \%)$ & $36(43 \%)$ & $6(7 \%)$ & \\
\hline Stiffness $[\mathrm{kPa}]$ & $11.0 \pm 8.6$ & $13.2 \pm 11.8$ & $11.2 \pm 11.9$ & n. s. \\
\hline $\begin{array}{l}\text { APRI score } \\
\text { (median, range) }\end{array}$ & $\begin{array}{l}2.7 \pm 7.1 \\
(0.9 ; 0.3-43.2)\end{array}$ & $\begin{array}{l}1.4 \pm 1.2 \\
(0.8 ; 0.4-5.7)\end{array}$ & $\begin{array}{l}1.1 \pm 0.6 \\
(1.3 ; 0.5-1.8)\end{array}$ & n. $s$ \\
\hline $\begin{array}{l}\text { FIB-4 score } \\
\text { (median, range) }\end{array}$ & $\begin{array}{l}3.8 \pm 8.2 \\
(1.6 ; 0.5-50.3)\end{array}$ & $\begin{array}{l}2.2 \pm 2.0 \\
(1.5 ; 0.7-10.7)\end{array}$ & $\begin{array}{l}2.2 \pm 1.3 \\
(1.6 ; 0.9-3.8)\end{array}$ & n. s. \\
\hline AST [U/1] & $65 \pm 41$ & $57 \pm 33$ & $64 \pm 39$ & n. s. \\
\hline $\mathrm{ALT}[\mathrm{U} / 1]$ & $84 \pm 52$ & $74 \pm 47$ & $94 \pm 87$ & n. s. \\
\hline Thrombocytes [T/1] & $163 \pm 77$ & $157 \pm 58$ & $181 \pm 55$ & n. s. \\
\hline $\begin{array}{l}\text { HCV-load } \\
\text { Undetectable: } \\
\text { low }(<800000 \mathrm{IU} / 1) \\
\text { high }(>800000 \mathrm{IU} / \mathrm{l})\end{array}$ & $\begin{array}{l}9(21 \%) \\
6(14 \%) \\
27(64 \%)\end{array}$ & $\begin{array}{l}5(14 \%) \\
8(23 \%) \\
22(63 \%)\end{array}$ & $6(100 \%)$ & n. s. \\
\hline $\begin{array}{l}\text { HCV-genotype } \\
1 \\
2 \\
3 \\
4 \\
\end{array}$ & $\begin{array}{l}20(54 \%) \\
5(14 \%) \\
10(27 \%) \\
2(5 \%)\end{array}$ & $\begin{array}{l}29(88 \%) \\
1(3 \%) \\
2(6 \%) \\
1(3 \%)\end{array}$ & $\begin{array}{l}3(60 \%) \\
1(20 \%) \\
1(20 \%)\end{array}$ & $\mathrm{p}=0.03$ \\
\hline HAART & $34(81 \%)$ & $31(86 \%)$ & $4(67 \%)$ & n. s. \\
\hline 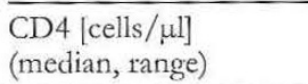 & $\begin{array}{l}428(52-1757) \\
428(52-1757)\end{array}$ & $\begin{array}{r}366(10-966) \\
356\end{array}$ & $\begin{array}{l}268(85-1056) \\
1056)\end{array}$ & $\mathrm{P}=0.02$ \\
\hline$<50$ HIV copies $/ \mathrm{ml}$ & $35(83 \%)$ & $23(64 \%)$ & $4(67 \%)$ & n. s. \\
\hline
\end{tabular}

Table 3. Changes in surrogate markers of liver fibrosis in HIV/HCV infection in the longitudinal analysis.

\begin{tabular}{|c|c|c|c|c|c|c|}
\hline HCV genotype & & & & & non 1 & all \\
\hline IL28B genotype & $\begin{array}{c}C C \\
n=13(33 \%)\end{array}$ & $\begin{array}{c}\text { CT } \\
\mathrm{n}=23(59 \%)\end{array}$ & $\begin{array}{c}\mathrm{TT} \\
\mathrm{n}=3(8 \%)\end{array}$ & $\begin{array}{c}\text { all } \\
(\mathrm{n}=39)\end{array}$ & $\begin{array}{c}\text { all } \\
(\mathrm{n}=15)\end{array}$ & $\begin{array}{c}\text { all } \\
(\mathrm{n}=56)\end{array}$ \\
\hline $\begin{array}{l}\text { Change of } \\
\text { Stiffness/month } \\
{[\mathrm{kPa} / \text { month] }}\end{array}$ & $-0.08 \pm 0.2$ & $0.003 \pm 0.4$ & $0.2 \pm 0.4$ & $-0.01 \pm 0.4$ & $0.04 \pm 0.4$ & $0.003 \pm 0.4$ \\
\hline $\begin{array}{l}\text { Change of APRI / } \\
\text { month }\end{array}$ & $0.001 \pm 0.06$ & $-0.007 \pm 0.05$ & $0.006 \pm 0.01$ & $-0.004 \pm 0.05$ & $-0.06 \pm 0.3$ & $-0.02 \pm 0.1$ \\
\hline $\begin{array}{l}\text { Change of FIB- } 4 \text { / } \\
\text { month }\end{array}$ & $-0.01 \pm 0.05$ & $0.01 \pm 0.07$ & $0.02 \pm 0.03$ & $0.008 \pm 0.06$ & $-0.04 \pm 0.3$ & $-0.006 \pm 0.2$ \\
\hline Period [months] & $19(5-48)$ & $27(12-50)$ & $49(14-50)$ & $22(5-50)$ & $24(9-47)$ & $25(5-50)$ \\
\hline
\end{tabular}

\section{Discussion}

In this cohort of $\mathrm{HIV} / \mathrm{HCV}$ co-infected patients with a high proportion of haemophiliacs we analysed the relationship between the rs $12979860 \mathrm{C} / \mathrm{T}$ polymorphism in the IL $28 B$ gene and progression of liver fibrosis applying both a cross-sectional comparison and a longitudinal study over 25 months.

In the cross-sectional analysis, we could not find any correlation between surrogate markers of liver fibrosis and genotypes in the IL $28 B$ gene. However, we observed a significantly higher progression rate of liver fibrosis in the follow-up of patients infected by HCV genotype 1, who carried a $\mathrm{T}$ allele. This observa- tion is in line with a previous study on HCV mono-infected patients in the context of liver transplantation [9], which reported a higher $T$ allele frequency in patients with viral cirthosis compared to patients with cirrhosis of non-viral origin or healthy controls. Thus, our data now provide first evidence that also HIV-positive patients with $\mathrm{HCV}$ genotype 1 co-infection show different rates of liver fibrosis progression depending on IL $28 B$ genotypes.

The fact that we observed an effect only in the follow-up group but not in the cross-sectional study quite likely reflects that fibrosis progression is determined by various factors such as different duration of viral infection and quality of HIV control. These fac- 
tors may have been better controlled for in the followup study. As patients with a T allele showed a trend towards a longer observation period, we standardised fibrosis progression rates to the time of the follow-up. Normalized rates of changes in liver stiffness confirmed the negative effect of the rs12979860 $\mathrm{T}$ allele.

An unexpected finding was the apparent association between IL $28 B$ genotypes and CD4 counts. This relationship remains unexplained at present. Leukopenia is associated with advanced liver disease. However, the absence of any association between the IL28B alleles and liver stiffness makes it an unlikely cause for this CD4 relationship. Alternatively serum levels of lambda interferons, which are coded for in the region of the rs12979860 C/T polymorphism, may be higher in carricrs of the $C$ allele, thus possibly contributing to better antiviral control both in HIV and HCV infection $[18,19]$.

Initially, an association between the rs12979860 $\mathrm{C} / \mathrm{T}$-polymorphism and response to standard treatment in HCV mono-infected patients was reported for HCV genotype 1 [20]. It is not clear in how far this polymorphism predicts definitive treatment response in HCV genotype 2 and $3[21,22]$. The association between rs12979860 polymorphism and treatment response was also only confirmed for genotypes 1 and 4 in HCV/HIV co- infected patients while data are contradictory for genotype 2 and 3 [23, 24]. This may explain why we observed an effect only in patients with HCV genotype 1. Another explanation might be the relatively low number of patients infected with other $\mathrm{HCV}$ genotypes in our cohort. Beyond that, we confirmed in our HIV/HCV co-infected patients that IL $28 \mathrm{~B}$ allele frequency differs between patients infected by different HCV genotypes [25], since a CC frequency of $39 \%$ was found in HCV genotype 1 infection versus $74 \%$ in $\mathrm{HCV}$ genotype non-1 infections ( $p$ $=0.006$ ).

So far, the molecular effect of the II $28 B$ mutation on HCV replication has not been established. A reduced hepatic expression of interferon-stimulated genes in the favourable genotype [26] was reported, but another group found no direct influence of IL $28 \mathrm{~B}$ mutations on the expression of interferon-stimulated genes [27]. Still, contradictory findings could be explained by different effects of IL $28 B$ genotypes on gene expression in different intrahepatic cell populations [28]. Thus, the rs12979860 polymorphism could influence liver fibrosis progression via differential expression of interferon-stimulated genes. Another possible mechanism could involve upregulation of CXCL9 in the CC-genotype of the rs12979860 polymorphism [26]. CXCL9 has been found to have antifibrotic properties [29].

Unfortunately this study has a couple of limitations. The cross-sectional study was done retrospectively and the cohort is rather small with only two years of follow-up. Although differences in probe position, different operator experience and low grade of fibrosis may have resulted in variability of transient elastography measurements [30], several studies confirm good reproducibility of transient elastography [31, 32]. Nevertheless, transient elastography can be limited by liver steatosis, a common problem in HIV/HCV co-infect- ed patients [33]. However, in contrast to HCV monoinfected patients or acute viral hepatitis, chronic inflammation does not seem to interfere with transient elastography in HIV/HCV co-infected patients [34].

The high proportion of haemophiliacs might be advantageous to study genetic host factors, because they are less exposed to potentially confounding factors such as hepatotoxic agents, which must for example be considered in i. v. drug injecting patients. It was also a particular strength of our study that results were obtained from a follow-up which provided a defined reference frame for interpreting fibrosis progression.

Concerning serum markers of liver fibrosis APRI or FIB-4 scores, effects due to the IL $28 B$ polymorphism were seen only with respect to FIB-4 score. This discrepancy can be attributed to the fact that the errors in measuring each single score component may have added up unfavourably, so that total variability of APRI and FIB-4 scores may have exceeded the effect, in the face of an overall low fibrosis progression in our cohort.

\section{CONCLUSION}

In addition to adherence to HAART [35] and CD4 counts [36], differences in distribution of IL $28 B$ alleles might explain divergent rates of liver fibrosis progression in cohorts of HIV/HCV co-infected paticnts. Carriers of the rs12979860 T'T genotype infected with HIV and HCV genotype 1 could be at a high risk for end stage liver disease. A long-term prospective study is warranted to confirm the long-term impact of IL $28 \mathrm{~B}$ alleles on the outcome of $\mathrm{HCV}$ co-infection in HIV-positive patients.

\section{REFERENCES}

1. Bühler S, Söllner J, Seybold U, Bogner JR. [Causes of death in HIV patients]. MMW Fortschr Med. 2009 Apr 30;151(18):56-57.

2. Bica I, McGovern B, Dhar R, Stone D, McGowan K, Scheib R, Snydman DR. Increasing mortality due to endstage live disease in patients which human immuno-deficiency Virus infection. Clin Infect Dis. $2001 \mathrm{Feb}$ $1 ; 32(3): 492-7$

3. Torriani FJ, Rodriguez-Torres M, Rockstroh JK, Lissen E, Gonzalez-García J, Lazzarin A, Carosi G, Sasadeusz J, Katlama C, Montaner J, Sette H Jr, Passe S, De Pamphilis J, Duff F, Schrenk UM, Dieterich DT; APRICOT Study Group. Peginterferon Alfa-2a plus ribavirin for chronic hepatitis $C$ virus infection in HIV-infected patients. N Engl J Med. 2004 Jul 29;351(5):438-50

4. Macías J, Berenguer J, Japón MA, Girón JA, Rivero A, López-Cortés LF, Moreno A, González-Serrano M, Iribarren JA, Ortega E, Miralles P, Mira JA, Pineda JA. Fast fibrosis progression between repeated liver biopsies in patients coinfected with human immunodeficiency virus/hepatitis C virus. Hepatology. 2009 Oct;50(4):105663

5. Sulkowski MS, Mehta SH, Torbenson MS, Higgins Y, Brinkley SC, de Oca RM, Moore RD, Afdhal NH, Thomas DI. Rapid fibrosis progression among HIV/hepatitis C virus-co-infected adults. AIDS. 2007 Oct 18;21(16):2209-16.

6. Bräu N, Salvatore M, Ríos-Bedoya $\mathrm{CF}$, Fernández-Carbia A, Paronetto F, Rodrígucz-()rengo JF, Rodríguez-Torres M. Slower fibrosis progression in HIV/HCV-coinfected 
patients with successful HIV suppression using antiretroviral therapy. Hepatol. 2006 Jan;44(1):47-55.

7. Souza AR, Tovo CV, Mattos AA, Chaves S. There is no difference in hepatic fibrosis rates of patients infected with hepatitis $\mathrm{C}$ virus and those co-infected with HIV. Braz J Med Biol Res. 2008 Mar;41(3):223-8.

8. Thomas DI, Thio CL, Martin MP, Qi Y, Ge D, O'Huigin C, Kidd J, Kidd K, Khakoo SI, Alexander G, Goedert JJ, Kirk GD, Donfield SM, Rosen HR, Tobler LH, Busch MP, McHutchison JG, Goldstein DB, Carrington M. Genetic variation in IL28B and spontaneous clearance of hepatitis C virus. Nature. 2009 Oct 8;461(7265):798-801.

9. Fabris C, Falleti E, Cussigh $\Lambda$, Bitetto D, Fontanini E, Bignulin S, Cmet S, Fornasiere E, Fumolo E, Fangazio S, Cerutti A, Minisini R, Pirisi M, Toniutto P. II - $28 B$ rs $12979860 \mathrm{C} / \mathrm{T}$ allele distribution in patients with liver cirrhosis: Role in the course of chronic viral hepatitis and the development of HCC. J Hepatol. 2010 Sep 19. [Epub ahead of print]

10. Bedossa P, Dargere D, Paradis V. Sampling variabilitiy of liver fibrosis in chronic hepatitis C. Hepatology. 2003 Dec;38(6):1449-57.

11. Castera L, Forns X, Alberti A. Non-invasive evaluation of liver fibrosis using transient elastography. J Hepatol. 2008 May;48(5):835-47

12. Sánchez-Conde M, Montes-Ramírez ML, Miralles P, Alvarez JM, Bellón JM, Ramírez M, Arribas JR, Gutiérrez I, López JC, Cosín J, Alvarez E, González J, Berenguer J. Comparison of transient elastography and liver biopsy for the assessment of liver fibrosis in HIV/hepatitis C viruscoinfected patients and correlation with noninvasive serum markers. J Viral Hepat. 2010 Apr;17(4):280-6.

13. Wai CT, Greenson JK, Fontana RJ, Kalbfleisch JD, Marrero JA, Conjeevaram HS, Lok A. A Simple Noninvasive Index Can Predict Both Significant Fibrosis and Cirrhosis in Patients With Chronic Hepatitis C. IIepatology. 2003 Aug;38(2):518-26.

14. Sterling RK, Lissen E, Clumeck N, Sola R, Correa MC, Montaner J, S Sulkowski M, Torriani FJ, Dieterich DT, Thomas DL, Messinger D, Nelson M; APRICOT Clinical Investigators. Development of a Simple Noninvasive Index to Predict Significant Fibrosis in Patients With HIV/HCV Coinfection. Hepatology. 2006 Jun;43(6): 1317-25.

15. Grünhage F, Wasmuth JC, Herkenrath S, Vidovic N, Goldmann G, Rockstroh J, Lammert F, Oldenburg J, Sauerbruch T, Spengler U. Transient elastography discloses identical distribution of liver fibrosis in chronic hepatitis $\mathrm{C}$ between HIV-negative and HIV-positive patients on HAART. Eur J Med Res. 2010 Apr 8;15(4):139-44.

16. Vidovic N, Lochowsky RS, Goldmann G, Rockstroh J, Wasmuth JC, Spengler U, Sauerbruch T, Lammert F, Oldenburg J, Grünhage F. Correlation of transient elastography with APRI and FIB-4 in a cohort of patients with congenital bleeding disorders and HCV or HIV/HCV coinfection. Haemophilia. 2010 Sep 1;16(5): 778-85.

17. Nattermann J, Vogel M, Berg T, Danta M, Axel B, Mayr C, Bruno- R, Tural C, Klausen G, Clotet B, Lutz T, Grünhage F, Rausch M, Nischalke HD, Schewe K, Bienek B, Haerter G, Sauerbruch T, Rockstroh JK, Spengler U; Kompetenznetz HIV/AIDS. Effect of the interleukin-6 C174G gene polymorphism on treatment of acute and chronic hepatitis $\mathrm{C}$ in human immunodeficiency virus coinfected patients. Hepatology. 2007 Oct;46(4):1016-25.

18. Hou W, Wang X, Ye L, Zhou L, Yang ZQ, Riedel E, Ho WZ. Lambda interferon inhibits human immunodeficiency virus type 1 infection of macrophages. J Virol. 2009 Apr;83(8):3834-42.

19. Langhans B, Kupfer B, Braunschweiger I, Arndt S, Schulte W, Nischalke HD, Nattermann J, Oldenburg J,
Sauerbruch T, Spengler U. Interferon-lambda serum levels in hepatitis C. J Hepatol. 2010 Oct 23. [Epub ahead of print]

20. Ge D, Fellay J, Thompson AJ, Simon JS, Shianna KV, Urban TJ, Heinzen EL, Qiu P, Bertelsen $A H$, Muir AJ, Sulkowski M, McHutchison JG, Goldstein DB. Genetic variation in IL28B predicts hepatitis C treatment-induced viral clearance. Nature. 2009 Sep 17;461(7262):399-401.

21. Mangia A, Thompson AJ, Santoro R, Piazzolla V, Tillmann HL, Patel K, Shianna KV, Mottola I, Petruzzellis D, Bacca D, Carretta V, Minerva N, Goldstein DB, McHutchison JG. Interleukin -28 B polymorphism determines treatment response of patients with hepatitis $C$ genotype 2 or 3 who do not achieve a rapid virologic response. Gastroenterology, 2010 Sep;139(3):821-7, 827.e1.

22. McCarthy JJ, Li JH, Thompson A, Suchindran S, Lao XQ, Patel K, Tillmann HL, Muir AJ, McHutchison JG. Replicated association between an II.28B gene variant and a sustained response to pegylated interferon and ribavirin. Gastroenterology. 2010 Jun;138(7):2307-14.

23. Ralló NI, Naggie S, Benito JM, Medrano J, Restrepo C, Goldstein D, Shianna KV, Vispo E, Thompson A, McHutchison J, Soriano V. Association of a single nucleotide polymorphism near the interleukin-28B gene with tesponse to hepatitis $C$ therapy in HIV/hepatitis C viruscoinfected patients. AIDS. 2010 May 15;24(8):F23-9.

24. Pineda $J \Lambda$, Caruz $\Lambda$, Rivero A, Neukam K, Salas I, Camacho A, Palomares JC, Mira JA, Martínez A, Roldán C, de la Torre J, Macías J. Prediction of Response to Pegylated Interferon plus Ribavirin by IL28B Gene Variation in Patients Coinfected With HIV and Hepatitis C Virus. Clin Infect Dis. 2010 Oct 1;51(7):788-95.

25. Montes-Cano MA, García-Lozano JR, Abad-Molina C, Romero-Gómez M, Barroso N, Aguilar-Reina J, NúñezRoldán A, González-Escribano MF. Interleukin-28B genetic variants and hepatitis virus infection by different viral genotypes. Hepatology. 2010 Jul;52(1):33-7.26.

26. Urban TJ, Thompson AJ, Bradtick SS, Fellay J, Schuppan D, Cronin KD, Hong L, McKenzie A, Patel K, Shianna KV, McHutchison JG, Goldstein DB, Afdhal N. II.28B genotype is associated with differential expression of intrahepatic interferon-stimulated genes in patients with chronic hepatitis C. Hepatology. 2010 Dec;52(6):1888-96.

27. Dill MT, Duong FH, Vogt JE, Bibert S, Bochud PY, Terracciano $\mathrm{L}$, Papassotiropoulos $\mathrm{A}$, Roth $\mathrm{V}$, Heim $\mathrm{MH}$. Interferon-Induced Gene Expression Is a Stronger Predictor of Treatment Response than $1 \mathrm{~L} 28 \mathrm{~B}$ Genotype in $\mathrm{Pa}$ tients with Hepatitis C. Gastroenterology. 2010 Nov 24. [Epub ahead of print]

28. Chen I, Borozan I, Sun J, Guindi M, Fischer S, Feld J, Anand N, Heathcote J, Edwards AM, McGilvray ID. Cell-type specific gene expression signature in liver underlies response to interferon therapy in chronic hepatitis C infection. Gastroenterology. 2010 Mar;138(3):112333.e1-3.

29. Wasmuth HE, Lammert F, Zaldivar MM, Weiskirchen R, Hellerbrand C, Scholten D, Berres ML, Zimmermann H, Streetz KL, Tacke F, Hillebrandt S, Schmitz P, Keppeler H, Berg T, Dahl E, Gassler N, Friedman SL, Trautwein C. Antifibrotic effects of CXCL9 and its receptor CXCR3 in livers of mice and humans. Gastroenterology. 2009 Jul;137(1):309-19, 319.e1-3.

30. Ingiliz P, Chhay KP, Munteanu M, Lebray P, Ngo Y, Roulot D, Benhamou Y, Thabut D, Ratziu V, Poynard T. Applicability and variability of liver stiffness measurements according to probe position. World J Gastroenterol. 2009 Jul 21;15(27):3398-404.

31. Fraquelli M, Rigamonti C, Casazza G, Conte D, Donato MF, Ronchi G, Colombo M. Reproducibility of transient elastography in the evaluation of liver fibrosis in patients with chronic liver disease. Gut. 2007 Jul;56(7):968-73. 
32. Roulot D, Czernichow S, Le Clésiau H, Costes JL, Vergnaud AC, Beaugrand M. Liver stiffness values in apparently healthy subjects: influence of gender and metabolic syndrome. J Hepatol. 2008 Apr;48(4):606-13.

33. Machado MV, Oliveira AG, Cortez-Pinto $H$. Hepatic steatosis in patients coinfected with human immunodeficiency virus/hepatitis $\mathrm{C}$ virus: A meta-analysis of the risk factors. Hepatology 2010; 52: 71-78.

34. Vispo E, Barreiro P, Del Valle J, Maida I, de Ledinghen V, Quereda C, Moreno A, Macías J, Castera L, Pineda JA, Soriano V. Overestimation of liver fibrosis staging using transient elastography in patients with chronic hepatitis C and significant liver inflammation. Antivir Ther. 2009; 14(2):187-93.

35. Qurishi N, Kreuzberg C, Iüchters G, Effenberger W, Kupfer B, Sauerbruch T, Rockstroh JK, Spengler U. Effect of antiretroviral therapy on liver-related mortality in patients with HIV and hepatitis C virus coinfection. Lancet. 2003 Nov 22;362(9397):1708-13.

36. Pineda JA, García-García JA, Aguilar-Guisado M, RíosVillegas MJ, Ruiz-Morales J, Rivero A, del Valle J, Luque
R, Rodríguez-Baño J, González-Scrrano M, Camacho A, Macías J, Grilo I, Gómez-Mateos JM; Grupo para el Estudio de las Hepatitis Víricas de la Sociedad Andaluza de Enfermedades Infecciosas (SAEI). Clinical progression of hepatitis $C$ virus-related chronic liver disease in human immunodeficiency virus-infected patients undergoing highly active antiretroviral therapy. Hepatology. 2007 Sep;46(3):622-30.

Received: January 4, 2011 / Accepted: Marcb 16, 2011

Address for correspondence:

Ulrich Spengler, MD

Department of Internal Medicine I

University Hospital Bonn

Sigmund Freud Str. 25

53105 Bonn

Phone: +4922828716789

Гax: $\quad$ +4922828719822

E-mail: Ulrich.spengler@ukb.uni-bonn.de 